\title{
Determination of Photosynthetic Pigments in Fleabane BIOTYPes Susceptible and Resistant TO THE HeRBICIDE GLYPHOSATE $^{1}$
}

\author{
Determinação de Pigmentos Fotossintéticos em Biótipos de Buva Suscetível e Resistente ao \\ Herbicida Glyphosate
}

KASPARY, T.E. ${ }^{2}$, LAMEGO, F.P. ${ }^{3}$, CUTTI, L. ${ }^{2}$, AGUIAR, A.C.M. ${ }^{2}$, and BELLÉ, C. ${ }^{2}$

\begin{abstract}
Chlorophylls and carotenoids are the main photosynthetic pigment in plants. In the weeds, the greatest amount of photosynthetic pigments can result in high competitiveness of the species. The aim of this study was to quantify the content of photosynthetic pigments in biotypes of fleabane (Conyza bonariensis) susceptible and resistant to glyphosate, by two different methods, as well as a correlation between chlorophyll content obtained by portable and classical methodology (extractable chlorophyll). An experiment was conducted in greenhouse and laboratory, 2 x 5 factorial scheme, where factor A was equivalent to biotypes of fleabane (resistant and susceptible to glyphosate) and factor B to developmental stages plants (rosette vegetative I, II and III and reproduction). At all stages of development, fleabane plants were evaluated with the portable determiner (chlorophyll content) and then the same leaves were subjected to classical methodology laboratory (extractable pigments). The resistant biotype of fleabane showed higher contents of chlorophyll a, b, and total carotenoids, inferring a greater competitive potential regarding the susceptible population to the herbicide. The portable determiner of chlorophyll showed high correlation with the classical method of determination of photosynthetic pigments, and can thus be used to accurately assess this, saving time and reagents.
\end{abstract}

Keywords: Conyza bonariensis, chlorophyll, carotenoids, resistance.

RESUMO - Clorofilas e carotenoides são os principais pigmentos fotossintéticos em plantas. Nas plantas daninhas, a maior quantidade de pigmentos fotossintéticos pode resultar em elevada competividade da espécie. O objetivo deste trabalho foi quantificar o teor de pigmentos fotossintéticos em biótipos de buva (Conyza bonariensis) suscetivel e resistente ao herbicida glyphosate, por dois diferentes métodos, bem como estabelecer uma correlação entre o índice de clorofila obtido pelo equipamento portátil e a metodologia clássica (clorofila extraível). Um experimento foi conduzido em casa de vegetação e laboratório, em esquema fatorial $2 \times 5$, em que ofator A equivaleu aos biótipos de buva (resistente e suscetivel a glyphosate) e o fator $B$, a estádios de desenvolvimento das plantas (roseta, vegetativo I, II e III, e reprodutivo). Em todos os estádios de desenvolvimento, as plantas de buva foram avaliadas com o determinador portatil (indice de clorofila); em seguida, as mesmas folhas foram submetidas à metodologia clássica de laboratório (pigmentos extraiveis). $O$ biótipo de buva resistente apresentou maiores teores de clorofila $a, b$, total e carotenoides, demonstrando maior potencial competitivo frente ao biótipo suscetivel ao herbicida glyphosate. $O$ determinador portátil de clorofila apresentou alta correlação com o método clássico de determinação de pigmentos fotossintéticos, podendo, assim, ser usado com precisão na avaliação destes, proporcionando economia de tempo e reagentes.

Palavras-chave: Conyza bonariensis, clorofilas, carotenoides, resistência.

Recebido para publicação em 7.9.2013 e aprovado em 6.1.2014.

2 Programa de Pós-graduação em Agronomia: Agricultura e Ambiente - PPGAAA, Universidade Federal de Santa Maria, Campus de Frederico Westphalen-RS, Brasil, <Tiago_kaspary@yahoo.com.br >; ${ }^{3}$ Universidade Federal de Pelotas, Faculdade de Agronomia, Departamento de Fitossanidade, Pelotas-RS, Brasil. 


\section{INTRODUCTION}

Weeds negatively interfere in crops of economic interest, with varying intensity, depending on the time of occurrence, population and intrinsic competitive ability for each species. The competitiveness of a species is related to the efficient use of resources from the environment in which the plant is located, and solar radiation (light) is a significant component in the establishment of this relationship for some weed species (Rizzardi et al., 2001). In this context, the interception and use of light are made by the action of photosynthetic pigments, chlorophylls and carotenoids present in plants; those with greater ability to produce pigments may present advantages in using the light source and therefore will be more competitive. In the case of weeds, this adaptive advantage can ensure propagation and multiplication of the species, as they will have greater development than commercial crops.

Photosynthetic pigments that are present, their abundance and photosynthetic efficiency of the plant vary with the species and stage of development of this one (Schuelter et al., 2003; Streit et al., 2005). The chlorophylls are the main chloroplastidic pigments responsible for collecting solar radiation, which, during the process of photosynthesis, is converted into chemical energy in the form of ATP and NADPH (Marenco and Lopes, 2005). Chlorophyll $a$ is the most abundant pigment in plants, directly participating in the photochemical stage (the first stage of the photosynthetic process), while other pigments (chlorophyll $b$ and carotenoids) assist in absorbing light and transferring energy to the radiating centers of reaction, being called accessory pigments; the ratio of chlorophyll $a$ and $b$ is $3: 1$, respectively (Streit et al., 2005).

The light absorption by the chlorophylls occurs in the visible spectrum, but with each other distinctions. The largest amount of energy is absorbed by chlorophyll $a$ near $660 \mathrm{~nm}$, while chlorophyll $b$ has two absorption peaks: the first one occurs near $500 \mathrm{~nm}$, and the second, at $650 \mathrm{~nm}$ (Di Vittorio, 2009). Regarding the carotenoids, which have the function of protecting the photosynthetic system against oxidative damage caused by overexposure to the sun, they have their absorption spectrum in the range of 410 a $510 \mathrm{~nm}$ (Dias and Marenco, 2007). The behavior of the differential absorption among photosynthetic pigments should be emphasized.

The determination of the chlorophyllian pigments by the classical methodology constitutes the destructive collection of vegetable leaf, in addition to represent a costly practice, involving several steps and the use of laboratory reagents. Unlike, the portable readers of chlorophyll use non-destructive, simple and instant principles, allowing leaf ontogenetic studies of the crops (Salla et al., 2007). Portable chlorophyll meters are being used successfully in the determination of photosynthetic pigments in different species, as reported by Torres Netto; Campostrini, (2005) in coffee (Coffea arabica); Ciganda et al. (2009) in corn (Zea mays); Busato et al. (2010) in potato (Solanum tuberosum); Rigon et al. (2012, 2013) in sesame (Sesamum indicum) and Jatropha (Jatropha curcas); and by Brito et al. (2011) in cotton (Gossypium hirsutum).

The relative chlorophyll content determined by portable chlorophyll meters is calculated from the amount of light transmitted by the leaf by means of wavelengths with different absorbencies, which instantaneously provide a single reading proportional to the chlorophylls $a$ and $b$ and to the carotenoids (Rigon et al., 2012). Portable determiners operate in two or three wavelengths: the SPAD Minolta chlorophyll meter uses two LEDs in the ranges of 650940 nanometers (nm), while the ClorofiLOG 1030 operates in 635, 660 and $850 \mathrm{~nm}$ (Rigon et al., 2012). However, the models that describe the relationship between the readings of the portable equipment and the classic determinations range among plants, according to the characteristics intrinsic to each species, requiring independent calibration (Uddling et al., 2007).

Fleabane (Conyza bonariensis) is an important species belonging to the Asteraceae family and is currently featured as the main weed infesting summer crops in southern Brazil, especially after the evolution of resistance to glyphosate herbicide. As a consequence, the adoption of alternative control measures or alternative herbicides is 
required, not always effective and often of higher cost.

The development of herbicide-resistant weeds may cause changes in plant physiology, which may be either beneficial or harmful to the ecological adaptability. Sibony and Rubin (2003) reported that mutations in the target site of action of the herbicide cause resistance, but did not affect the adaptability of the species of Amaranthus blitoides, resistant to the sulfometuron herbicide, an inhibitor of acetolactate synthase (ALS) enzyme. In studies with biotypes of Conyza canadensis resistant to glyphosate, greater initial vigor was observed for these compared to the susceptible biotype (Shrestha et al., 2010), which may have ecological significance for the population dynamics of the species. However, the less efficient photosynthetic activity, due to changes in the sites of action of herbicides in the membranes of chloroplasts, is considered the reason for the lower photosynthetic potential and physiological penalty on biotypes of plants resistant to triazines and inhibitors of photosystem 2 (Christoffoleti et al., 1994).

In studies developed by Shrestha et al. (2010) with biotypes of Conyza canadensis resistant and susceptible to glyphosate, a shortest period of time necessary for resistant plants to reach flowering and seed production was observed when compared to the susceptible ones, growing in a similar environment. These results demonstrate greater initial development for resistant biotypes, providing greater initial competitive potential when compared to the susceptible biotype. This may be associated with a better ability to use environmental resources, including solar radiation, facilitated by greater leaf area, which would favor the uptake of radiation, or a possible increased presence of photosynthetic pigments in the resistant biotype. For Fleck et al. (2003), a higher rate of net accumulation and high growth rate are related to high levels of chlorophyll in the leaves.

From the hypothesis that fleabane biotypes resistant to glyphosate have higher photosynthetic capacity due to a higher content of chlorophylls and carotenoids, it can be inferred that they may be more competitive and harmful to crops, requiring the adoption of new management strategies, not only for herbicide resistance but also by the higher competitiveness. Thus, the quick review of the competitive characteristics of a weed population may favor the anticipation in decision making of this species, preventing it to be established and perpetuated. The aim of this study was to quantify and compare the content of photosynthetic pigments of Conyza bonariensis susceptible and resistant to glyphosate by two methods of determination, extractable chlorophyll and the chlorophyll meter readings, and to assess whether there is significant correlation between the methods.

\section{MATERIALS AND METHODS}

This study was conducted in a greenhouse and laboratory of the Department of Enviromental and Agronomic Sciences from Universidade Federal de Santa Maria (UFSM), Frederico Westphalen Campus, from October 2012 to January 2013. Fleabane seeds, biotype $\mathrm{S}$ (susceptible) from Frederico Westphalen and biotype $R$ (resistant) originating from commercial farming in the Brazilian municipality of Jaboticaba-RS, were sown in plastic cups with a volume of $50 \mathrm{~mL}$ filled with agricultural substrate (TecnoMax) and after presenting two leaves, were transplanted to plastic pots with a volume of $6 \mathrm{~L}$, filled with the same substrate.

The experimental design used was completely randomized, arranged in a $2 \times 5$ factorial design, with factor A corresponding to the biotypes of fleabane (susceptible and resistant to glyphosate herbicide) and factor B at five stages of plant development (stage of rosette, vegetative stages I, II and III and reproductive stage).

For the assessments of the photosynthetic pigments contents, in each stage of development, two leaves from the middle third of four plants of each biotype were analyzed and subsequently collected, totaling eight replicates per treatment. The relative chlorophyll content was measured individually by the ClorofiLOG $1030^{\circledR}$ portable reader method; reading was performed directly on the leaves, without them being removed from the plant, and the results were expressed as chlorophyll level (Falker, 2013). Then, the same leaves were collected and wrapped in 
aluminum foil for protection against sun radiation and placed in a cool box to avoid denaturation of enzymes and proteins. The samples were then taken to the laboratory for analysis by the extractable method, according to the methodology proposed by Hiscox and Israelstam (1979).

For dissolving the samples, $0.05 \mathrm{~g}$ of fresh weight of leaves was placed in test tubes, where were added $3 \mathrm{~mL}$ of reagent dimethyl sulfoxide (DMSO), and incubated at $65^{\circ} \mathrm{C}$ for $45 \mathrm{~min}$ in a water bath. Then, hand stirring was performed, adding $2 \mathrm{~mL}$ more of $\mathrm{DMSO}$, for 30 seconds. The final solution containing the pigments was read in a Biomate ${ }^{{ }^{\mathrm{tm}} 3}$ spectrophotometer, by means of the wavelengths of 470, 645 and $663 \mathrm{~nm}$ for carotenoids, chlorophyll $b$ and chlorophyll $a$, respectively. The values were measured from the transfer of $2.5 \mathrm{~mL}$ of aliquot to a disposable cuvette with a volume of $3 \mathrm{~cm}^{3}$. The values obtained for each wavelength were used in the equations reported byLichtenthaler (1987), based on fresh weight (MF), when the contents of chlorophyll $a, b$, total chlorophyll and carotenoids were determined, expressed in mg g ${ }^{-1}$.

The data obtained for each method were subjected to analysis of variance by $\mathrm{F}$ test, and the treatment means were compared by Tukey test at 5\% probability. Correlation analysis between the extractable method and the chlorophyll meter readings were also performed. Adjustments of the curves were performed by linear and quadratic functions, according to the coefficient of determination, by means of the Sigmaplot ${ }^{\circledR} 11.2$ software.

\section{RESULTS AND DISCUSSION}

The characterization of the stage of the plants of fleabane during measurements by both methods is shown in Table 1. These averages were not compared statistically, but in absolute values; there is a further development of resistant plants, noting that both biotypes ( $R$ and $S$ ) were seeded on the same day.

As for the reading method of the chlorophyll meter employed, statistical significance was observed for interaction of the biotypes and stages factors $(p \leq 0.05)$ (Table 2$)$. In the comparison among biotypes, there was a higher relative chlorophyll level in the resistant ones at all stages of assessment. Higher levels of photosynthetic pigments may provide the biotype holder of this characteristic a better use of light from the environment and highest net accumulation of photoassimilates, besides a high growth rate (Fleck et al., 2003).

When comparing the levels of chlorophyll among the stages of development of the biotypes, the susceptible one showed higher values in the third vegetative stage, equivalent to 51.10 (Table 2), demonstrating a significant increase in its value from its establishment until now. Such behavior was also noticed by Schuelter et al. (2003) working with different tomato cultivars, found a differential behavior and reduction of chlorophyll content and carotenoids 60 days after implantation of the seedlings, causing early senescence of leaves. Moura (2004), in a study also with tomatoes, said that smaller fruits were generated by reduction of the photosynthetic rate due to the early fall of the chlorophyll content by the leaves.

For the susceptible biotype of fleabane, the early reduction in chlorophyll content could generate fewer viable seeds and/or less vigorous. As for the resistant biotype, this one presented a significant increase in the rate of chlorophyll from the rosette stage (initial) to the reproductive stage (Table 2).

In the assessment of photosynthetic pigments in Conyza bonariensis performed by the classical methodology (extractable chlorophyll, proposed by Hiscox and Israelstam, 1979), again a significant interaction for the factors evaluated was found $(p \leq 0.05)$ (Table 3). In all variables, the content of chlorophyll $a$, chlorophyll $b$ content, content of total chlorophyll and carotenoids, biotype $\mathrm{R}$ has higher values than biotype S. The data observed by the chlorophyll method are in accordance with those obtained by the traditional method. However, from the method of extractable chlorophyll were determined the contents of $a, b$, total chlorophyll and carotenoids, and for all variables the susceptible biotype showed lower performance.

In comparison to the classical methodology stages (extractable chlorophyll), biotype S 
Table 1 - Characterization of the stages of development of plants of biotypes of Conyza bonariensis, susceptible (S) and resistant (R) to the glyphosate herbicide. UFSM, Campus of Frederico Westphalen-RS, 2012/13

\begin{tabular}{|c|l|c|c|c|c|c|}
\hline \multirow{2}{*}{ Biotype } & \multicolumn{1}{|c|}{ Variables } & $\begin{array}{c}\text { Rosette }^{1 /} \\
\left(42^{*}\right)\end{array}$ & $\begin{array}{c}\text { Vegetative I } \\
(69)\end{array}$ & $\begin{array}{c}\text { Vegetative II } \\
(86)\end{array}$ & $\begin{array}{c}\text { Vegetative III } \\
(105)\end{array}$ & $\begin{array}{c}\text { Reproductive } \\
(124)\end{array}$ \\
\cline { 3 - 8 } & & $3.4^{* *}$ & 13.2 & 36.2 & 52.8 & 64.5 \\
\hline \multirow{3}{*}{$\mathrm{S}$} & Size (cm) & 11.3 & 41.8 & 141.3 & 307.5 & 402.8 \\
\cline { 2 - 8 } & Number of leaves (no.) & 10.7 & 14.8 & 20.3 & 30.0 & 33.5 \\
\cline { 2 - 8 } & Diameter of the rosette (cm) & 4.2 & 15.2 & 69.2 & 92.3 & 106.4 \\
\hline \multirow{3}{*}{$\mathrm{R}$} & Size (cm) & 12.5 & 52.3 & 253.8 & 467.3 & 562.3 \\
\cline { 2 - 8 } & Number of leaves (no.) & 11.8 & 18.9 & 31.2 & 43.2 & 48.2 \\
\cline { 2 - 8 } & Diameter of the rosette (cm) & & & & & \\
\hline
\end{tabular}

* Day after the emergence; ** average of four plants. $\mathrm{S}=$ susceptible; $\mathrm{R}=$ resistant. ${ }^{1}$ rosette - absence of apical growth with lateral expansion of the leaves; vegetative stage I - early elongation of the main stem; vegetative stage II - full elongation of the main stem; vegetative stage III - maximum elongation of the main stem; reproductive stage - first flower bud formed.

Table 2 - Relative chlorophyll level in Conyza bonariensis biotypes, susceptible and resistant to glyphosate herbicide, determined by the chlorophyll meter method (ClorofiLOG). UFSM, Campus of Frederico Westphalen-RS, 2012/13

\begin{tabular}{|l|c|c|c|c|c|}
\hline \multirow{2}{*}{ Biotype } & \multicolumn{5}{|c|}{ Stage } \\
\cline { 2 - 6 } & Rosette $^{1 /}$ & Vegetative I & Vegetative II & Vegetative III & Reproductive \\
\hline $\mathrm{S}$ & $\mathrm{b}^{3 /} 41.10 \mathrm{D}$ & $\mathrm{b} 45.95 \mathrm{C}$ & $\mathrm{b} 48.37 \mathrm{~B}$ & $\mathrm{~b} 51.10 \mathrm{~A}$ & $\mathrm{~b} 45.71 \mathrm{C}$ \\
\hline $\mathrm{R}$ & $\mathrm{a} 45.62 \mathrm{E}$ & $\mathrm{a} 55.45 \mathrm{D}$ & $\mathrm{a} 61.44 \mathrm{C}$ & $\mathrm{a} 65.19 \mathrm{~B}$ & $\mathrm{a} 70.12 \mathrm{~A}$ \\
\hline Average & 43.36 & 50.70 & 54.91 & 58.15 & 57.92 \\
\hline $\mathrm{CV}^{2 /}(\%)$ & & & 6.95 & \\
\hline
\end{tabular}

1/ rosette - absence of apical growth with lateral expansion of the leaves; vegetative stage I - early elongation of the main stem; vegetative stage II - full elongation of the main stem; vegetative stage III - maximum elongation of the main stem; reproductive stage - first flower bud formed. ${ }^{2 /}$ Coefficient of variation. ${ }^{3 /}$ Similar capital letters in the line and lowercase letters in the column do not differ by Tukey test at $5 \%$ significance.

showed again significant increase for chlorophyll $a$, chlorophyll $b$, total chlorophyll and carotenoids (Table 3 ) until the vegetative stage III, followed by reduction in the reproductive growth stage. As for biotype $R$, the increase occurred progressively from the rosette to the reproductive stages, in all variables analyzed.

By correlating the results obtained by the method of chlorophyll meter and chlorophyll $a$ content determined in the laboratory, there is a high relationship among the readings, with a coefficient of determination of 0.97 and 0.98 for the susceptible biotypes (Figure 1A) and resistant ones (Figure 1B), respectively. Thus, it is noticed that the readings obtained by the portable equipment accurately estimate the chlorophyll content in leaves of Conyza bonariensis. Thus, the mathematical model generated in (Figures 1A, B) can be used reliably to estimate the chlorophyll a content in Conyza bonariensis. These results reinforce what has already been observed by Rigon et al. (2012), who, when working with the crops of sesame, also found a high correlation between chlorophyll meter readings (level) with chlorophyll $a$ extracted in the laboratory.

When the correlation was performed for chlorophyll $b$, again the ratio between what was observed by the portable equipment and what was measured in the laboratory showed a high coefficient of determination, with a value of 0.90 for biotype $S$ and 0.97 for biotype $R$ (Figures 1C, D). However, Neves et al. (2005) stress that the reading of chlorophyll $b$ via portable devices is more difficult than the measurement of chlorophyll $a$. This is related to the fact that the wavelength emitted by the device is closer to the absorption peak of chlorophyll $a$, which is $660 \mathrm{~nm}$, while the absorption of pigment $b$ shows two peaks, the 
Table 3 - Content of chlorophyll $a$, chlorophyll $b$, total chlorophyll and carotenoids $\left(\mathrm{mg} \mathrm{g}^{-1} \mathrm{mf}\right.$ ), determined by the classical methodology, in biotypes of Conyza bonariensis, susceptible (S) and resistant (R) to the glyphosate herbicide. UFMS, Campus of Frederico Westphalen-RS, 2012/13

\begin{tabular}{|c|c|c|c|c|c|}
\hline \multirow{2}{*}{ Biotype/Stage } & \multicolumn{5}{|c|}{ Chlorophyll $a$} \\
\hline & Rosette $^{1 /}$ & Vegetative I & Vegetative II & Vegetative III & Reproductive \\
\hline $\mathrm{S}$ & $\mathrm{b}^{3 /} 0.9980 \mathrm{D}$ & b $1.1083 \mathrm{C}$ & b $1.214 \mathrm{~B}$ & b $1.2877 \mathrm{~A}$ & b $1.1206 \mathrm{C}$ \\
\hline $\mathrm{R}$ & a $1.1139 \mathrm{E}$ & a $1.3274 \mathrm{D}$ & a $1.7437 \mathrm{C}$ & a $1.934 \mathrm{~B}$ & a $2.3066 \mathrm{~A}$ \\
\hline Average & 1.0560 & 1.2179 & 1.4789 & 1.6109 & 1.7136 \\
\hline \multirow[t]{2}{*}{$\mathrm{CV}^{2 /}(\%)$} & \multicolumn{5}{|c|}{3.84} \\
\hline & \multicolumn{5}{|c|}{ Chlorophyll $b$} \\
\hline $\mathrm{S}$ & b $0.2170 \mathrm{C}$ & b $0.2218 \mathrm{BC}$ & b $0.2645 \mathrm{~A}$ & b $0.2700 \mathrm{~A}$ & b $0.2295 \mathrm{~B}$ \\
\hline $\mathrm{R}$ & a $0.2372 \mathrm{E}$ & a $0.3097 \mathrm{D}$ & a $0.3539 \mathrm{C}$ & a $0.3987 \mathrm{~B}$ & a $0.4637 \mathrm{~A}$ \\
\hline Average & 0.25 & 0.27 & 0.31 & 0.33 & 0.35 \\
\hline \multirow[t]{2}{*}{$\mathrm{CV}(\%)$} & \multicolumn{5}{|c|}{3.49} \\
\hline & \multicolumn{5}{|c|}{ Total chlorophyll } \\
\hline $\mathrm{S}$ & b $1.2150 \mathrm{D}$ & b $1.3301 \mathrm{C}$ & b $1.4785 \mathrm{~B}$ & b $1.5577 \mathrm{~A}$ & b $1.3500 \mathrm{C}$ \\
\hline $\mathrm{R}$ & a $1.3510 \mathrm{E}$ & a $1.6371 \mathrm{D}$ & a $2.0912 \mathrm{C}$ & a $2.3327 \mathrm{~B}$ & a $2.7703 \mathrm{~A}$ \\
\hline Average & 1.2830 & 1.4836 & 1.7849 & 1.9452 & 2.0602 \\
\hline \multirow[t]{2}{*}{$\mathrm{CV}(\%)$} & \multicolumn{5}{|c|}{2.79} \\
\hline & \multicolumn{5}{|c|}{ Carotenoids } \\
\hline $\mathrm{S}$ & b $0.3657 \mathrm{D}$ & b $0.3982 \mathrm{C}$ & b $0.4427 \mathrm{~B}$ & b $0.4761 \mathrm{~A}$ & b $0.4052 \mathrm{C}$ \\
\hline $\mathrm{R}$ & a $0.4036 \mathrm{D}$ & a $0.5093 \mathrm{C}$ & a $0.5393 \mathrm{~B}$ & a $0.5993 \mathrm{~A}$ & a $0.5915 \mathrm{~A}$ \\
\hline Average & 0.3847 & 0.4538 & 0.4910 & 0.5377 & 0.4984 \\
\hline $\mathrm{CV}(\%)$ & \multicolumn{5}{|c|}{2.70} \\
\hline
\end{tabular}

${ }^{1 /}$ rosette - absence of apical growth with lateral expansion of the leaves; vegetative stage I - early elongation of the main stem; vegetative stage II - full elongation of the main stem; vegetative stage III - maximum elongation of the main stem; reproductive stage - first flower bud formed. ${ }^{2 /}$ Coefficient of Variation. ${ }^{3 /}$ Similar capital letters in the line and lowercase letters in the column do not differ by Tukey test at $5 \%$ significance.

first close to $500 \mathrm{~nm}$ and the other close to $650 \mathrm{~nm}$ (Vittorio, 2009). However, this study demonstrated a high efficiency in chlorophyll meter readings in relation to laboratory analysis for the species $C$. bonariensis.

In terms of the values concerning the total chlorophyll, high correlation coefficients (0.92 and 0.98) were observed between the rate noticed by means of chlorophyll and extraction in the laboratory, allowing the adjustment to a mathematical model of high reliability during analysis of the biotypes $\mathrm{S}$ and R, respectively (Figures 1E, F). Brito et al. (2011) and Rigon et al. (2012, 2013) also observed a high correlation coefficient among the methods of determination of pigments in cotton, sesame and jatropha, respectively.

The correlation between the level observed by the chlorophyll meter and the content of carotenoids in leaves of Conyza bonariensis is shown in (Figures 2A, B); the coefficients of determination presented again showed up high, being 0.93 for biotype $\mathrm{S}$ and 0.96 for biotype $\mathrm{R}$. It is emphasized that the determination of carotenoids is important, since they act as sunscreens in photosystem II, dissipating the energy excess incurring on the leaf in the form of light, thus avoiding, by means of its high antioxidant potential, that the chlorophylls be damaged (Li et al., 2010). The ratio among chlorophylls and carotenoids changes as the plant is subjected to some stress, especially when subjected to water stress (Young and Britton, 1990).

The relationship between the values of total chlorophyll divided by the content of carotenoids showed a determination coefficient of 0.89 and 0.93 for $S$ and $R$, respectively (Figure 2C, D). Hendry and Price (1993) emphasize that the relationship 
between the concentration of total chlorophyll and carotenoids concentration is important for protection against stress by photo-oxidation, mainly in leaf senescence. Relations between chlorophylls also serve as ambiance parameter for the plant (Hendry \& Price 1993). Thus, biotype $\mathrm{R}$ has greater protection capacity of

\section{Susceptible}
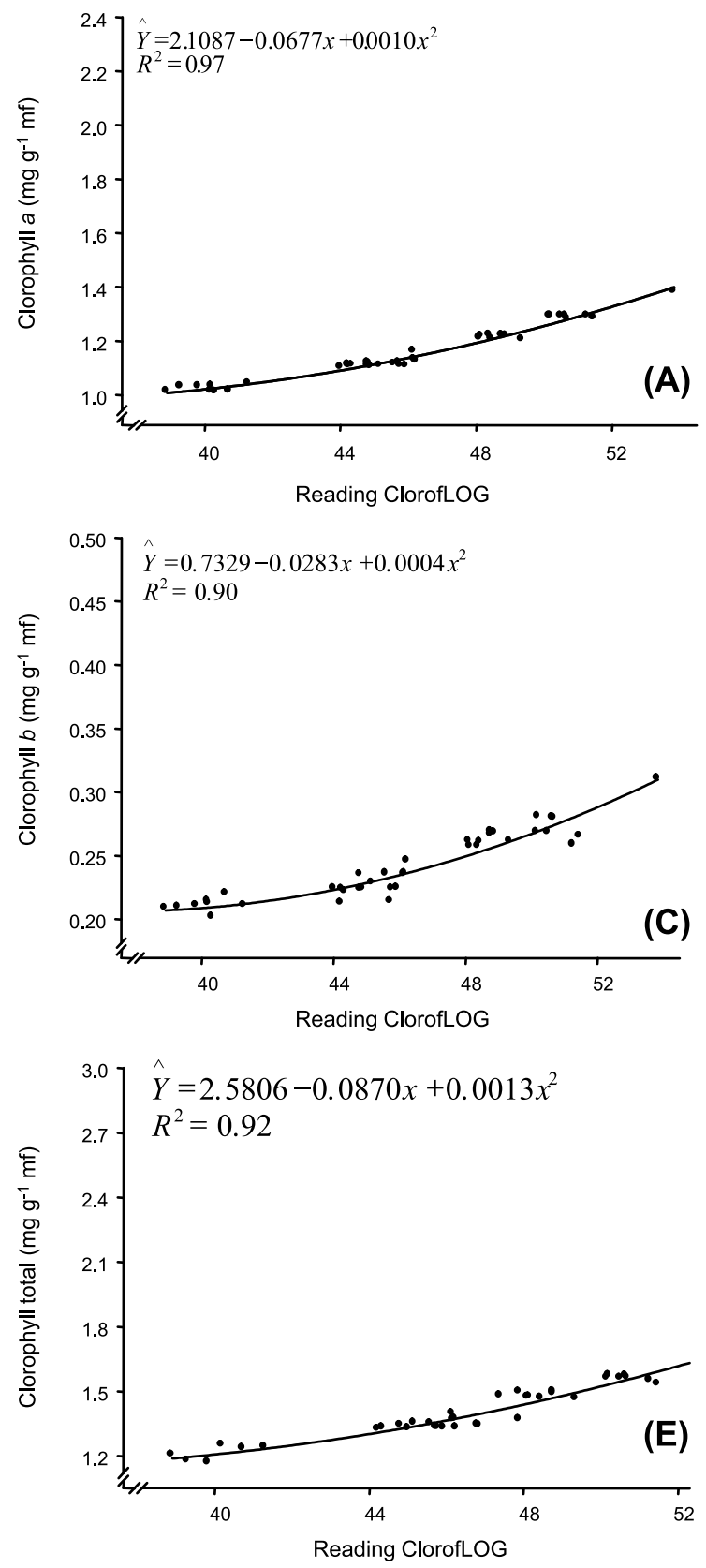

chlorophylls by carotenoids, as well as a better adaptive capacity when compared to biotype S.

In Figures $2 \mathrm{E}, \mathrm{F}$ is described the relationship between chlorophyll a/chlorophyll $b$ determined in laboratory and the level of chlorophyll obtained with the chlorophyll
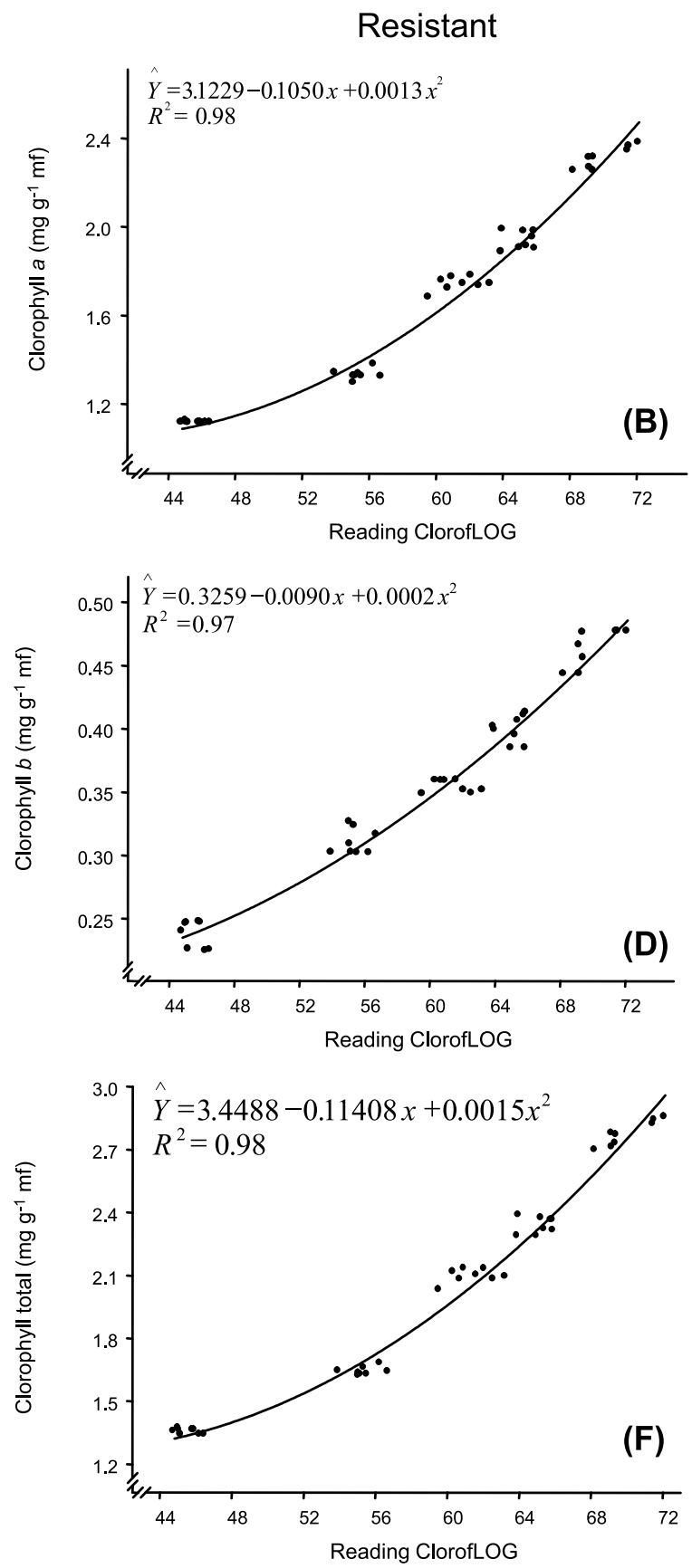

Figure 1 - Ratio between the reading of the portable ClorofiLOG ${ }^{\circledR}$ chlorophyll meter and contents of chlorophyll $a$ (A- susceptible and B- resistant), chlorophyll $b$ (C-susceptible and D- resistant) and total chlorophyll (E- susceptible and F- resistant), in Conyza bonariensis. UFSM, Campus of Frederico Westphalen-RS, 2012/13. 

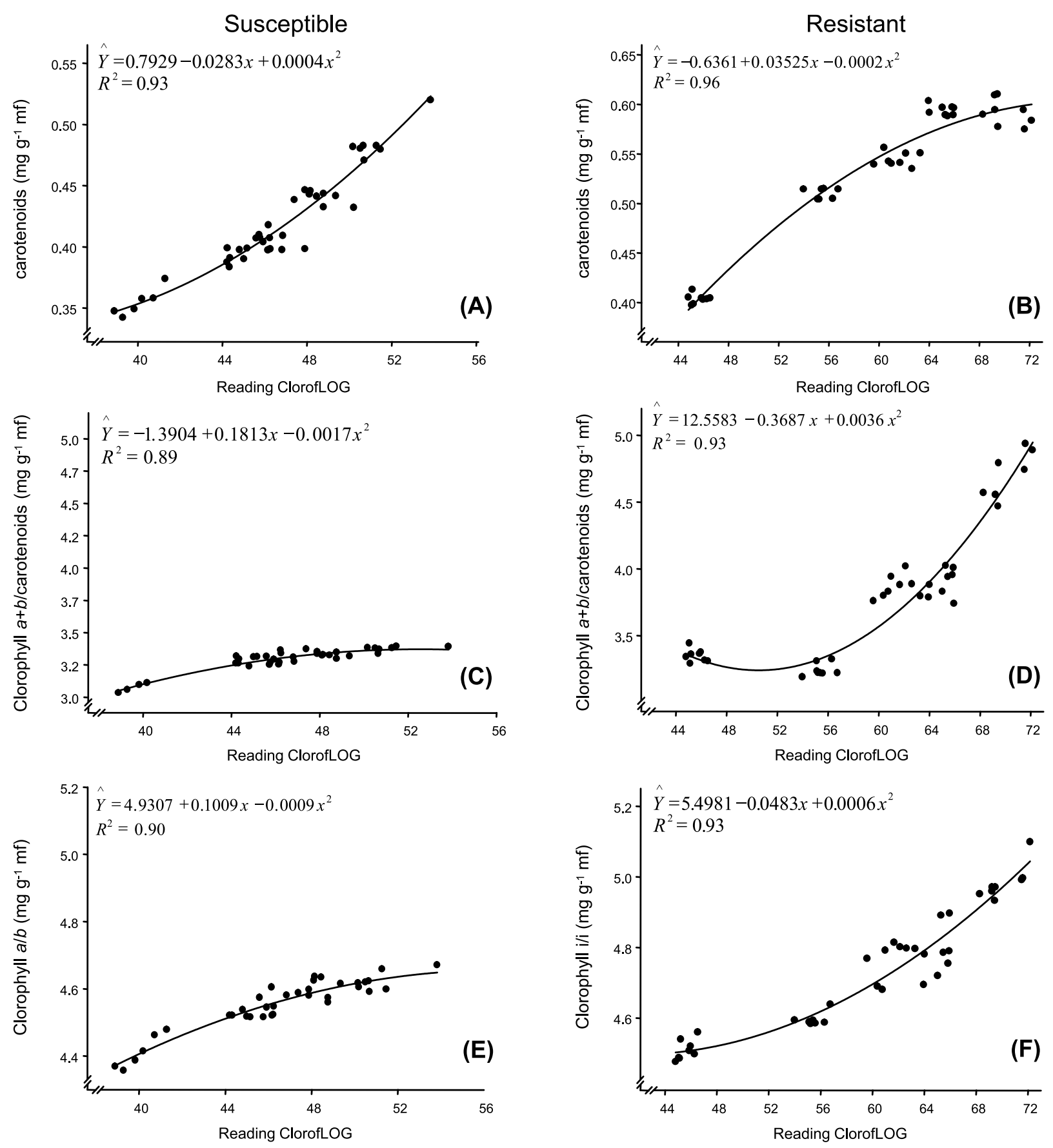

Figure 2 - Ratio between the reading of the portable ClorofiLOG ${ }^{\circledR}$ chlorophyll meter and contents of carotenoids (A- susceptible and B- resistant), chlorophyll $\mathrm{a}+\mathrm{b} /$ carotenoids (C susceptible and D resistant) and chlorophyll $\mathrm{a} / \mathrm{b}$ (E- susceptible and F- resistant), in Conyza bonariensis. UFSM, Campus of Frederico Westphalen-RS, 2012/13.

meter; the correlations among the values show the coefficient of determination of 0,90 for biotype $\mathrm{S}$ and 0.93 for the resistant biotype. This ratio expresses the plant's capacity to capture light under shade conditions, as reported by Nakazono et al. (2001). Thus, fleabane plants of biotype $R$, even shaded, will have a better performance compared to biotype S, also shaded. Results with high values of determination were also observed by Torres Netto and Campostrini (2005), using SPAD-502 as a portable chlorophyll meter in 
coffee, with coefficients of determination of 0.92. As for Rigon et al. (2013), when using the portable ClorofiLOG determiner for the crop of jatropha, obtained a coefficient of determination of 0.73. A high initial development and the total accumulation of photoassimilates for the resistant biotype may involve high interspecific competitive ability for this species. The photosynthetic efficiency and accumulation of assimilates, as well as growth, are directly associated with, among other factors, the levels of leaf chlorophyll (Souza et al., 2010). Thus, from the upper levels of chlorophyll observed for biotype $\mathrm{R}$, it is possible to infer its high competitive ability. Thus, once this situation occurred in the field, the biotype of $C$. bonariensis $\mathrm{S}$ would be suppressed in the presence of the resistant one, even with the absence of applications of glyphosate herbicide. However, in the competition with crops, biotype $\mathrm{R}$ would be even more damaging and require more attention in management, which could generate additional costs to its control.

Based on the determination of photosynthetic pigments, it is possible to infer that the biotype of fleabane resistant to glyphosate has superior competitive ability for this variable when compared to the susceptible biotype, taking advantage of growth conditions in the absence of the herbicide. It is possible to accurately determine the photosynthetic pigments in plants of $C$. bonariensis through the use of portable chlorophyll meter adjusted with mathematical models, providing savings in time and reagents.

\section{ACKNOWLEDGMENT}

To FAPERGS (Fundo de Amparo à Pesquisa (Foundation for Research Support)), by the scholarship and finantial support to the resource; to the chemistry laboratory of UFSM (Universidade Federal de Santa Maria) Campus of Frederico Westphalen; colleagues from the masters course, who helped with the protocol; and to Professor Antônio Luis Santi, for lending the ClorofiLOG equipment.

\section{LITERATURE CITED}

BRITO, G. G. et al. Non-destructive analysis of photosynthetic pigments in cotton plants. Acta Sci. Agron., v. 33, n. 4 , p. 671-678, 2011.
BUSATO, C. et al. Seasonal variation and threshold values for chlorophyll meter readings on leaves of potato cultivars.

J. Plant Nutr., v. 33, n. 4, p. 2148-2156, 2010.

CHRISTOFFOLETI, P. J.; VICTORIA FILHO, R.; SILVA, C. B. Resistência de plantas daninhas aos herbicidas.

Planta Daninha, v. 12, n. 1, p. 13-20, 1994.

CIGANDA, V.; GITELSON, A. A.; SCHEPERS, J. Nondestructive determination of maize leaf and canopy chlorophyll content. J. Plant Physiol., v. 166, n. 1, p. 157-167, 2009.

DI VITTORIO, A. V. Enhancing a leaf radiative transfer model to estimate concentrations and in-vivo specific absorption coefficients of total carotenoids and chlorophylls a and b from single-needle reflectance and transmittance. Remote Sens. Environ., v. 113, n. 9 , p. 1948-1966, 2009.

DIAS, D. P.; MARENCO, R. A. Fotossíntese e fotoinibição em mogno e acariquara em função da luminosidade e temperatura foliar. Pesq. Agropec. Bras., v. 42, n. 2 , p. 305-311, 2007.

FALKER - Automação agrícola. Medidor eletrônico de teor de clorofila: dados técnicos clorofiLOG CFL1030. Rev. C Set. 2009. 6 p. Disponível em: <http://www.falker.com.br/ download.php?file_id=74>. Acesso em: 27 out. 2013.

FLECK, N. G. et al. Velocidade de estabelecimento em cultivares de arroz irrigado como característica para aumentar a habilidade competitiva com plantas concorrentes. $\mathbf{C i}$. Rural, v. 33, n. 4, p. 635-640, 2003.

HENDRY, G. A. F.; PRICE, A. H. Stress indications: chlorophylls and carotenoids. In: HENDRY, G. A. F.; GRIME, J. P., ed. Methods in comparative plant ecology. London: Chapman and Hall, 1993. p. 148-152.

HISCOX, J. D.; ISRAELSTAM, G. F. A method for the extraction of chlorophyll from leaf tissue without maceration. Canadian J. Bot., v. 57, n. 12, p. 1132-1334, 1979.

LI, R. et al. Effects of salt and alkali stresses on germination, growth, photosynthesis and ion accumulation in alfalfa (Medicago sativa L.). Soil Sci. Plant Nutr., v. 56, p. $725-733,2010$.

LICHTENTHALER, H. K. Chlorophylls and carotenoids: pigments of photosynthetic biomembranes. In: PACKER, L.; DOUCE, R., ed. Methods in enzymology. London: Academic Press, 1987. v. 148. p. 350-382.

MARENCO, R. A.; LOPES, N. F. Fisiologia vegetal: fotossíntese, respiração, relações hídricas e nutrição mineral. Viçosa, MG: Universidade Federal de Viçosa, 2005. $451 \mathrm{p}$.

Planta Daninha, Viçosa-MG, v. 32, n. 2, p. 417-426, 2014 
MOURA, M. L. et al. Crescimento e desenvolvimento de frutos do tomateiro 'Santa Clara' e do seu mutante natural 'firme'. Ci. Agrotecnol., v. 28, n. 6, p. 1284-1290, 2004.

NAKAZONO, E. M. et al. Crescimento inicial de Euterpe edulis Mart. em diferentes regimes de luz. R. Bras. Bot., v. 24, n. 2 , p. $173-179,2001$.

NEVES, O. S. C. et al. Uso do SPAD-502 na avaliação dos teores foliares de clorofila, nitrogênio, enxofre, ferro e manganês do algodoeiro herbáceo. Pesq. Agropec. Bras., v. 40, n. 5 , p. $517-521,2005$.

RIGON, J. P. G. et al. Indirect measurement of photosynthetic pigments in the leaves of Jatropha curcas. Semina: Ci. Agr., v. 34, n. 2, p. 669-674, 2013.

RIGON, J. P. G. et al. Análise não destrutiva de pigmentos fotossintéticos em folhas de gergelim. R. Bras. Eng. Agríc. Amb., v. 16, n. 3, p. 258-261, 2012.

RIZZARDI, M. A. et al. Competição por recursos do solo entre ervas daninhas e culturas. Ci. Rural, v. 31, n. 4 , p. 707-714, 2001.

SALLA, L.; RODRIGUES, J. C.; MARENOS, R. A. Teores de clorofila em árvores tropicais determinados com

SPAD-502. R. Bras. Bioci., v. 5, n. 1, p. 59-161, 2007.

SCHUELTER, A. R. et al. Avaliação dos níveis de clorofila em folhas de tomateiro da cultivar Santa Clara, do mutante 'firme' e do híbrido F1. Acta Sci.. Biol. Sci., v. 25, n. 1, p. 183-187, 2003.
SHRESTHA, A. et al. Growth, Phenology, and Intraspecific Competition between Glyphosate-Resistant And Glyphosate-Susceptible Horseweeds (Conyza canadensis) in the San Joaquin Valley of California. Weed Sci., v. 58, n. 2, p. $147-153,2010$.

SIBONY, M.; RUBIN, B. The ecological fitness of Amaranthus retroflexus and $\mathrm{A}$. blitoides resistant to acetolactate synthase inhibitors and atrazine. Weed Res., v. 43 , n. 1 , p. 40-47, 2003.

SOUSA, J. V. et al. Silicato de potássio via foliar no milho: fotossíntese, crescimento e produtividade. Biosci. J., v. 26, n. 4, p. 502-513, 2010.

STREIT, N. M. et al. As clorofilas. Ci. Rural, v. 35, n. 3, p. $748-755,2005$.

TORRES NETTO, A.; CAMPOSTRINI, E. Photosyntheticpigments, nitrogen, chlorophyll a fluorescence and -502 readings in coffee leaves. Sci. Hortic., v. 104, n. 2, p. 199-209, 2005.

UDDLING, J. et al. Evaluating the relationship between leaf chlorophyll concentration and SPAD-502 chlorophyll meter readings. J. Photosy. Res., v. 91, n. 1, p. 37-46, 2007.

YOUNG, A.; BRITTON, G. Carotenoids and stress. In: ALSCHER, R. G.; CUMMINGS, J. R. Stress responses in plants: Adaptation and acclimation mechanisms. New York: Wiley-Liss, 1990. p. 87-112. 